\title{
ANALISIS PEMILIHAN LOKASI TEMPAT PEMBUANGAN SAMPAH DI KECAMATAN LOA KULU, KABUPATEN KUTAI KARTANEGARA
}

\author{
Lisa Astria Milasari \\ Program Studi Arsitektur, Fakultas Teknik \\ Universitas 17 Agustus 1945 Samarinda \\ E-mail : lisaastria71@gmail.com/HP.082251305285
}

\begin{abstract}
ABSTRAK
Besarnya penduduk dan keragaman aktivitas di Kota, mengakibatkan munculnya persoalan dalam pelayanan prasarana perkotaan, salah satunya masalah persampahan. Laju pertumbuhan penduduk akan berbanding lurus dengan tingkat konsumsi masyarakat, sehingga mengakibatkan permasalahan tentang sampah. Pengelolaan sampah yang terbatas dan kurang baik pada tempat pembuangan sampah menjadi salah satu faktor penyebabnya. Tujuan dari penelitian adalah mengetahui kesesuaian lokasi tempat pembuangan sementara (TPS) sampah di Kecamatan Loa Kulu, sehingga nantinya dapat diketahui pengelolaan persampahan sebagai acuan dalam menentukan lokasi. Penelitian ini menggunakan pendekatan rasionalisme, dimana dengan metode teoritik dan empiric yang berkaitan dengan identifikasi kriteria penentuan lokasi alternatif Tempat Pembuangan Sementara (TPS) Sampah berdasarkan fenomena permasalahan yang terjadi pada penyediaan prasarana persampahan yang belum ada secara optimal. Lokasi penelitian dilakukan di Kecamatan Loa Kulu, dikarenakan Kecamatan Loa Kulu merupakan kawasan perkotaan di Kabupaten Kutai Kartanegara. Metode analisis yang digunakan adalah analisis prioritas ini menggunakan alat analisis AHP. Dari hasil analisis, desa yang memiliki nilai tertinggi dan menjadi prioritas terpilih adalah desa Jembayan. Berdasarkan hasil analisa AHP dapat disimpulkan bahwa lokasi terpilih yaitu Jembayan 1 dengan jumlah lokasi 1,62, kepadatan penduduk dengan jumlah 0,48, dan jumlah untuk jarak TPS Ke TPA 0,9 sehingga jumlah total adalah 3. Berarti lokasi yang paling sesuai untuk lokasi tempat pembuangan sementara (TPS) sampah, karena memupakan lokasi agglomerasi pengelolaan sampah yang didukung dengan kondisi jalan yang baik (perkerasan aspal) serta banyaknya jumlah penduduk. Untuk lebih jelasnya dapat dilihat pada peta 2 lokasi terpilih sebagai lokasi tempat pembuangan sementara (TPS) sampah kabupaten Kutai Kartanegara.
\end{abstract}

Kata Kunci: pemilihan lokasi, tempat pembuangan sampah sementara

\section{ABSTRACT}

The large population growth and the diversity of activities in the city that have packaging problems in infrastructure infrastructure problems, one of which is the problem of solid waste. The rate of population growth will be directly proportional to the level of public consumption, causing problems related to waste. Limited and poor waste management at the TPA is one of the contributing factors. The purpose of this study was to determine the suitability of the location of the Temporary Waste Disposal Site (TPS) in Loa Kulu District, so that waste management can be used as a reference in determining the location. This research uses a rationalism approach, where theoretical and empirical methods are related to the criteria for determining alternative locations for temporary disposal sites (TPS) for waste based on the phenomenon of problems that occur in infrastructure infrastructure that does not exist optimally. The location of the research was conducted in Loa Kulu District, because Loa Kulu District is an urban area in Kutai Kartanegara Regency. The analytical method used is priority analysis using the AHP analysis tool. 
From the results of the analysis above, the village that has the highest value and becomes a priority is Jembayan village. Based on the results of the AHP analysis, it can be stated that the selected location is Jembayan 1 with a total of 1.62 locations, a population density of 0.48, and the distance from TPS to TPA is 0.9 so that the total number is 3. This means that the location is the most suitable for that location. Temporary Waste Disposal Sites (TPS), because they are locations for agglomeration of waste management that are supported by good road conditions (asphalt pavement) and a large population. For more details, it can be seen on the map 2 selected locations as TPS for waste in Kutai Kartanegara Regency.

Keywords : Location selection, temporary landfills

\section{PENDAHULUAN}

Kehidupan masyarakat tidak dapat dapat dipisahkan dengan lingkungan sosial dan lingkungan alamnya. Besarnya jumlah penduduk terhadap barang akan semakin besar volume sampah yang dihasilkan. Sampah biasanya dibuang ke tempat yang jauh dari permukiman atau tempat tinggal manusia. Pengelolaan sampah menjadi salah satu permasalahan yang dihadapi oleh masyarakat perkotaan. Proses pengelolaan sampah yang kurang baik akan menimbulkan lingkungan yang kurang menyenangkan bagi masyarakat yang tinggal disekitarnya, seperti menimbulkan bau kurang sedap dan pemandangan kurang enak dipandang. Sampah biasanya dibuang ke tempat jauh dari permukiman atau tempat hunian masyarakat. Jika tempat pembuangan sampah berada dekat dengan hunian masyarakat, risikonya akan menyebabkan pencemaran dan penyakit di area permukiman. Penanganan sampah merupakan salah satu output dari strategi nasional Sanitasi Total Berbasis Masyarakat. Selain itu, pengelolaan sampah telah diatur pada Undang-Undang Republik Indonesia Nomor 18 Tahun 2008 Tentang Pengelolaan Sampah dengan mengurangi dan menangani sampah, dengan cara berwawasan lingkungan. Sampah dari permukiman merupakan sampah dihasilkan oleh kegiatan atau lingkungan rumah tangga atau sering disebut dengan istilah sampah domestik. Dampak yang ditimbulkan dari akibat masalah sampah, antara lain perkembangan faktor penyakit, pencemaran udara, pencemaran air, pencemaran tanah, gangguan estetika, dan gangguan kebisingan, serta dampak sosial. Menurut Damanhuri (2008, hal. 40), pengelolaan sampah adalah pengumpulan, pengangkutan, pemrosesan, pendaurulangan, atau pembuangan dari material sampah. Pengelolaan sampah berbeda dengan daerah perkotaan dan pedesaan. Tempat penampungan sementara dalam SNI 19-2454-1991 tentang tata cara teknik operasional pengelolaan sampah disebut sebagai pewadahan komunal, yaitu aktivitas penampungan sampah sementara dalam suatu wadah bersama baik dari berbagai sumber maupun sumber umum. Permasalahan dalam pengelolaan sampah ini juga terjadi di Kecamatan Loa Kulu merupakan salah satu wilayah kawasan perkotaan di Kabupaten Kutai Kartanegara, yang saat ini belum memiliki tempat pembuangan sampah Kecamatan Loa Kulu. Di tahun 2020 Kecamatan Loa Kulu memiliki jumlah penduduk sebanyak 52.383 jiwa, yang terbagi menjadi 15 desa/kelurahan. Diperkirakan jumlah penduduk Kecamatan Loa Kulu ini akan terus mengalami peningkatan. Seperti yang terjadi di Kecamatan Loa Kulu Jumlah penduduk seringkali dipengaruhi berbagai macam faktor, hal ini menyebakan jumlah volume sampah yang dihasilkan mengalami peningkatan. Pemilihan lokasi tempat penampungan sementara (TPS) sampah merupakan salah satu indikator penting dalam pengelolaan sampah. Tujuan dari penelitian adalah merumuskan kriteria penentuan dan menganalisa alternatif lokasi tempat pembuangan sementara (TPS) sampah di Kecamatan Loa Kulu, sehingga nantinya dapat diketahui pengelolaan persampahan sebagai acuan dalam menentukan lokasi. 


\section{METODE PENELITIAN}

Penelitian ini menggunakan pendekatan rasionalisme, dimana dengan metode teoritik dan empiric yang berkaitan dengan identifikasi kriteria penentuan lokasi alternatif Tempat Pembuangan Sementara (TPS) Sampah berdasarkan fenomena permasalahan yang terjadi pada penyediaan prasarana persampahan yang belum ada secara optimal. Lokasi penelitian dilakukan di Kecamatan Loa Kulu, dikarenakan Kecamatan Loa Kulu merupakan kawasan perkotaan di Kabupaten Kutai Kartanegara. Kondisi permukiman perkotaan saat ini yang telah berkembang adalah di wilayah pusat-pusat kegiatan utama. Luas kawasan permukiman perkotaan di Kabupaten Kutai Kartanegara adalah \pm 21.171 hektar dan berlokasi pada pusat - pusat kegiatan PKW, PKL, dan PPK. Adapun variabel penelitian yang digunakan adalah kondisi fisik dasar, kerentanan terhadap rawan bencana, jarak permukiman, jarak dari badan air, jarak antara TPS ke TPA, kepadatan penduduk, tidak dalam kawasan lindung, wilayah yang belum terbangun, dan lokasi mudah diakses. Metode analisis yang digunakan adalah analisis prioritas ini menggunakan alat analisis AHP, yaitu salah satu pendekatan dalam pengambilan keputusan yang didisain untuk membantu pemecahan terhadap permasalahan yang kompleks dengan banyak kriteria dan melibatkan banyak kriteria pilihan. Penggunaan metode ini hanya pada penetuan prioritas kriteria yang digunakan, yaitu dengan menggunakan teknik perbandingan berpasangan kemudian diolah sehingga diperoleh bobot masing-masing kriteria.

\section{HASIL DAN PEMBAHASAN}

Kabupaten Kutai Kartanegara merupakan salah satu kabupaten di Provinsi Kalimantan Timur, dengan Ibukota yaitu Tenggarong. Kabupaten Kutai Kartanegara memiliki luas wilayah 27.263,10 km² dan luas perairan kurang lebih $4.097 \mathrm{~km}^{2}$. Dengan adanya perkembangan dan pemekaran wilayah, Kabupaten Kutai Kartanegara terbagi dalam 18 wilayah kecamatan dan 237 desa/ kelurahan. Salah satunya pada Kecamatan Loa Kulu merupakan salah satu Kecamatan di Kabupaten Kutai Kartanegara yang memiliki luas wilayah 1.045,7 $\mathrm{Km}^{2}$. Wilayah Kecamatan Loa Kulu berada di antara 116 29' Bujur Timur $-117^{0} 03^{\prime}$ B Bujur Timur dan 0 26' Lintang Selatan $-0^{0} 54^{\prime}$ ' Lintang Selatan. Secara administrastif, Kecamatan Loa Kulu memiliki 15 desa termasuk desa hasil pemekaran. Desa yang mengalami pemekaran yaitu desa Sumber Sari, Desa Jongkang dan Desa Sepakat. Dengan jumlah Rukun Tetangga (RT) di Kecamatan Loa Kulu sebanyak 199 RT. Untuk Desa Lung Anai memiliki wilayah terkecil yaitu 1,1 $\mathrm{m} 2$ hanya dibagi menjadi 4 RT, sedangkan Desa Margahayu memiliki jumlah RT terbanyak yakni 27 RT.

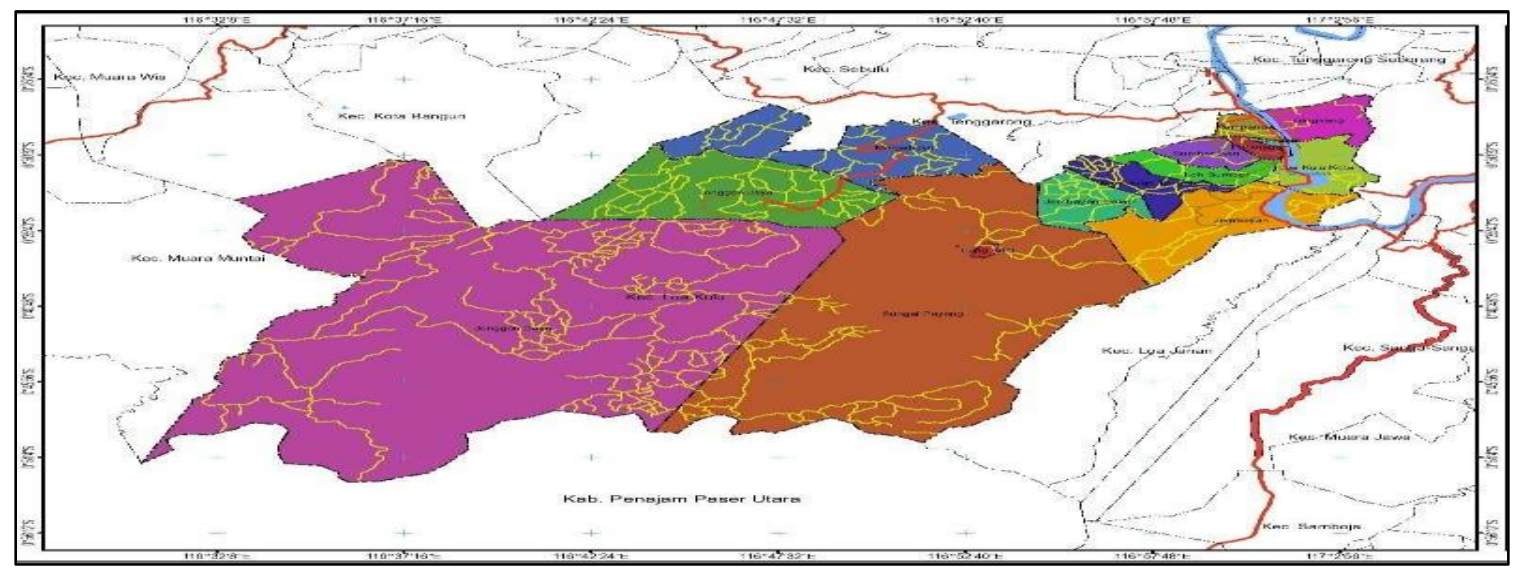

Gambar 1. Peta Kecamatan Loa Kulu, Kabupaten Kutai Kartanegara 
Produksi sampah di Kabupaten Kutai Kartanegara sebagian besar masih dikelola oleh Pemerintah Daerah. Pelayanan untuk satu Kecamatan secara keseluruhan baru meliputi 24\% dari seluruh areal pelayanan dan pengangkutan sampah. Kabupaten Kutai Kartanegara memiliki 1 TPS pada tiap Kecamatan. Dari hasil produksi sampah/timbulan sampah di Kabupaten Kutai kartanegara untuk sampah permukiman (rumah tangga) mencapai $2.917,53 \mathrm{~m}^{3} /$ hari dan sampah bukan hanya berasal dari domestik namun non domestik juga. Persentase komposisi timbulan sampah dapur $80 \%$ dan kertas-kertas $30 \%$. Hambatan lain adalah kondisi dan pandangan masyarakat terhadap pengelolaan sampah dan kesadaran masyarakat dalam mengelola sampah masih kurang. Permasalahan persampahan di permukiman perkotaan Kabupaten Kutai Kartanegara adalah sebagai beerikut aspek pengembangan sarana dan prasarana, pengumpulan setempat, penampungan sementara, dan pengangkutan, pengolahan akhir terpusat, daur ulang dan belum tersedianya masterplan dan dokumen lainnya terkait persampahan di Kabupaten Kutai Kartanegara. Jumlah TPS yang ada tidak mencukupi (hanya ada 8 unit TPS biasa dan 4 unit kontainer). Jumlah TPST hanya tersedia: 2 unit TPST, kapasitas total: 20 $\mathrm{m} 3 /$ hari atau setara dengan $0,21 \%$ dari timbulan sampah Kabupaten/Kota. Kriteria umum penentuan lokasi tempat pembuangan sementara (TPS) sampah, berdasarkan kajian tersebut adalah sebagai berikut :

1. Kondisi fisik dasar

2. Kerentanan terhadap rawan bencana

3. Jarak permukiman

4. Jarak dari badan air,

5. Jarak antara TPS ke TPA

6. Kawasan permukiman penduduk

7. Kepadatan penduduk,

8. Tidak dalam kawasan lindung,

9. Wilayah yang belum terbangun, dan

10. Lokasi mudah diakses

Secara keseluruan nilai bobot dari seluruh kriteria utama penentuan lokasi tempat pembuangan sementara sampah. Klasifikasi interval yang digunakan dalam penentuan lokasi tempat pembuangan sampah sementara terpilih yaitu dengan jumlah data tertinggi yaitu klasifikasi interval 1 dengan skor data tertinggi yang akan diprioritaskan sebagai lokasi desa terpilih tempat pembuangan sampah sementara. Berdasarkan quesioner yang telah penulis lakukan yaitu kepada sepuluh sampel yaitu 5 kelompok masyarakat (kecamatan, kantor desa, Dinas lingkungan hidup dan kehutanan Kabupaten Kutai Kartanegara, Bappeda Kabupaten Kutai Kartanegara dan Dinas Pekerjaan Umum Kabupaten Kutai Kartanegara). Berikut rekapan kuesioner pemilihan desa/Kelurahan terpilih untuk tempat pembuangan sampah sementara yakni.

Tabel 1. Rekapan Kuesioner Bobot untuk Kriteria Pemilihan Desa/kelurahan Terpilih

\begin{tabular}{|c|c|c|c|c|c|c|}
\hline \multirow{2}{*}{ Faktor Penentu } & \multicolumn{6}{|c|}{ Bobot } \\
\hline & 1 & 2 & 3 & 4 & 5 & Terpilih \\
\hline \multicolumn{7}{|c|}{ Lokasi } \\
\hline Kondisi Fisik Dasar & 2 & 1 & 3 & 1 & 3 & \multirow{3}{*}{5} \\
\hline $\begin{array}{l}\text { Kerentan terhadap rawan } \\
\text { bencana }\end{array}$ & 1 & 3 & 1 & 1 & 4 & \\
\hline Indeks & 42,86 & $\begin{array}{r}57,14 \\
\text { wil }\end{array}$ & $\begin{array}{l}57,14 \\
\text { lyah }\end{array}$ & 28,57 & 100 & \\
\hline
\end{tabular}




\begin{tabular}{|c|c|c|c|c|c|c|}
\hline \multirow{2}{*}{ Faktor Penentu } & \multicolumn{6}{|c|}{ Bobot } \\
\hline & 1 & 2 & 3 & 4 & 5 & Terpilih \\
\hline Wilayah belum terbangun & 1 & 2 & 2 & 2 & 3 & \multirow{3}{*}{5} \\
\hline Tidak dalam kawasan lindung & 1 & 1 & 2 & 1 & 5 & \\
\hline Indeks & 25 & 37,5 & 50 & 37,5 & 100 & \\
\hline \multicolumn{7}{|c|}{ Akses } \\
\hline Lokasi mudah diakses & 2 & 4 & 2 & 1 & 1 & \multirow{2}{*}{2} \\
\hline Indeks & 50 & 100 & 50 & 25 & 25 & \\
\hline \multicolumn{7}{|c|}{ Jarak } \\
\hline Jarak permukiman & 3 & 1 & 4 & 1 & 1 & \multirow{4}{*}{3} \\
\hline Jarak dari badan air & 2 & 3 & 2 & 1 & 2 & \\
\hline Jarak TPS ke TPA & 1 & 1 & 5 & 2 & 1 & \\
\hline Indeks & 54,55 & 45,45 & 100 & 36,36 & 36,36 & \\
\hline \multicolumn{7}{|c|}{ Penduduk } \\
\hline Kepadatan Penduduk & 1 & 1 & 2 & 4 & 2 & \multirow{3}{*}{4} \\
\hline Kawasan Permukiman penduduk & 1 & 1 & 1 & 6 & 1 & \\
\hline Indeks & 20 & 20 & 30 & 100 & 30 & \\
\hline
\end{tabular}

Sumber : hasil rekapan kuesioner, 2020

Tabel. 2. Prioritas Desa/Kelurahan Terpilih

\begin{tabular}{|r|l|c|}
\hline No & Desa/kelurahan & Prioritas lokasi \\
\hline 1 & Jonggon Desa & 6 \\
\hline 2 & Sungai Payang & 9 \\
\hline 3 & Jembayan & 1 \\
\hline 4 & Ponoragan & 11 \\
\hline 5 & Loh Sumber & 4 \\
\hline 6 & Loa Kulu Kota & 2 \\
\hline 7 & Rempanga & 5 \\
\hline 8 & Jonggon Raya & 8 \\
\hline 9 & Margahayu & 3 \\
\hline 10 & Long Anai & 15 \\
\hline 11 & Jembayan Tengah & 13 \\
\hline 12 & Jembayan Dalam & 12 \\
\hline 13 & Sumber Sari & 10 \\
\hline 14 & Sepakat & 14 \\
\hline 15 & Jongkang & 7 \\
\hline
\end{tabular}

Sumber : hasil analisis, 2020

Dari hasil analisis diatas, desa yang memiliki nilai tertinggi dan menjadi prioritas terpilih adalah desa Jembayan. Untuk penentuan desa terpiliih diambil dengan nilai lokasi 25 , nilai jarak 30, nilai akses 20, nilai wilayah 12 dan nilai penduduk 4, sehingga total nilai adalah 91 lebih unggul dibanding desa loa kulu kota adalah 75 . 
JURNAL KACAPURI

Selanjutnya dilakukan penentu titik lokasi dengan bantuan ahp dengan memasukkan hasil kuesioner yang telah dibagikan. Dalam teknik ini dilakukan pembobtan pada tiap-tiap peta tematik yang dilakukan proses overlay. Yaitu layak (3), kurang layak (2), dan tidak layak (1). Pada rancangan hirarki ini akan diperoleh satu lokasi yang akan digunakan sebagai lokasi yang berdasarkan pada tabel dibawah ini.

Tabel 3. Konsistensi

\begin{tabular}{|c|c|c|c|c|c|c|c|c|c|c|}
\hline Faktor Penentu & $\mathbf{A}$ & B & $\mathbf{C}$ & $\mathbf{E v}$ & Vp & VA & $\begin{array}{c}\lambda \\
(\mathbf{V A} / \mathbf{V p})\end{array}$ & $\lambda \operatorname{Max}$ & CI & CR \\
\hline A. Lokasi & 1 & 3 & 2 & 1,82 & 0,54 & 1,62 & 3,01 & \multirow{4}{*}{3,01} & \multirow{4}{*}{0,005} & \multirow{4}{*}{0,01} \\
\hline B. Kepadatan penduduk & 0,33 & 1 & 0,5 & 0,55 & 0,16 & 0,49 & 3,01 & & & \\
\hline C. Jarak TPS ke TPA & 0,5 & 2 & 1 & 1 & 0,30 & 0,89 & 3,01 & & & \\
\hline Jumlah & 1,8 & 6,0 & 3,5 & 3,37 & 1,00 & 3,01 & 9,03 & & & \\
\hline
\end{tabular}

Sumber : hasil analisis, 2020

Berdasarkan hasil analisa AHP dapat disimpulkan bahwa lokasi terpilih yaitu Jembayan 1 dengan jumlah lokasi 1,62, kepadatan penduduk dengan jumlah 0,48 , dan jumlah untuk jarak TPS Ke TPA 0,9 sehingga jumlah total adalah 3. Berarti lokasi yang paling sesuai untuk lokasi tempat pembuangan sementara (TPS) sampah, karena memupakan lokasi aglomerasi pengelolaan sampah yang didukung dengan kondisi jalan yang baik (perkerasan aspal) serta banyaknya jumlah penduduk. Berikut gambar peta lokasi tempat pembuangan sampah sementara di desa Jembayan RT. 22, Kecamatan Loa kulu, Kabupaten Kutai kartanegara.

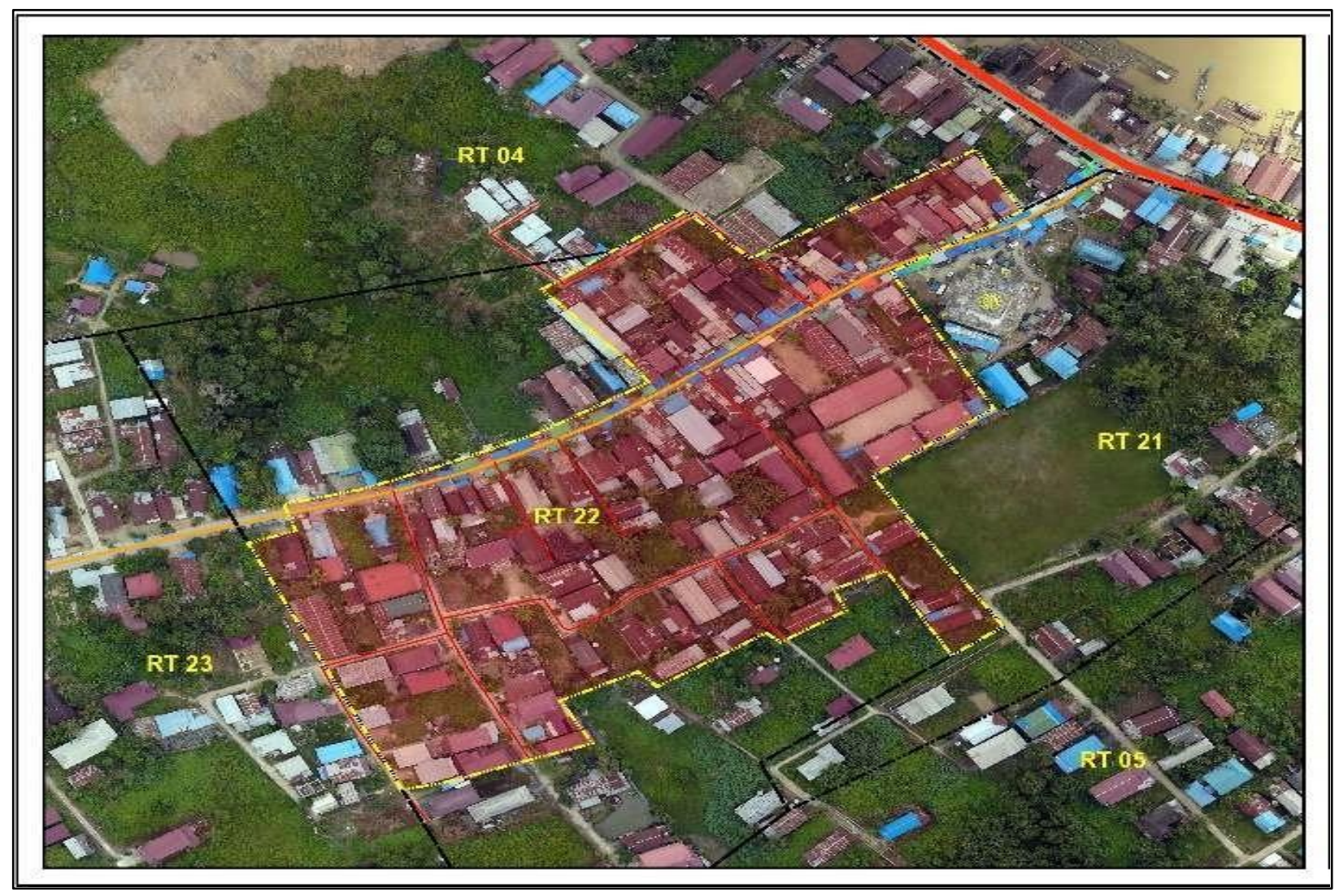

Gambar 2. Peta Lokasi Terpilih 


\section{PENUTUP}

Berdasarkan hasil analisis dan pembahasan dapat diambil kesimpulan yaitu dari hasil produksi sampah/timbulan sampah di Kabupaten Kutai kartanegara untuk sampah permukiman (rumah tangga) mencapai $2.917,53 \mathrm{~m}^{3} /$ hari dan sampah bukan hanya berasal dari domestik namun non domestik juga. Persentase komposisi timbulan sampah dapur $80 \%$ dan kertas-kertas $30 \%$. Selanjutnya pada analisis berikutnya desa yang memiliki nilai tertinggi dan menjadi prioritas terpilih adalah desa Jembayan. Untuk penentuan desa terpiliih diambil dengan nilai lokasi 25 , nilai jarak 30 , nilai akses 20 , nilai wilayah 12 dan nilai penduduk 4, sehingga total nilai adalah 91 lebih unggul disbanding desa loa kulu kota 75. Kemudian dari hasil analisa AHP dapat disimpulkan bahwa lokasi terpilih yaitu Jembayan 1 dengan jumlah lokasi 1,62, kepadatan penduduk dengan jumlah 0,48, dan jumlah untuk jarak TPS Ke TPA 0,9 sehingga jumlah total adalah 3 . Berarti lokasi yang paling sesuai untuk lokasi tempat pembuangan sementara (TPS) sampah, karena memupakan lokasi aglomerasi pengelolaan sampah yang didukung dengan kondisi jalan yang baik (perkerasan aspal) serta banyaknya jumlah penduduk.

Dari hasil penelitian ada beberapa saran yang dapat dikemukakan yaitu diperlukan penelitian kembali untuk menentukan lokasi yang sesuai berdasarkan alternatif lokasi yang sudah ditemukan serta kriteria yang digunakan merupakan hasil sintesa dari teori lokasi dan juga beberapa kajian topik serupa di wilayah lain.

\section{DAFTAR PUSTAKA}

1. Achmad, Ismid; Sudarma, I Made; Paturusi, dan Syamsul Alam. 2015. Strategi Penentuan Lokasi Dan Kebutuhan Lahan Tps (Tempat Penampungan Sementara Sampah) Berdasarkan Fungsi Kawasan Di Kota Denpasar. Ecotrophic : jurnal ilmu lingkungan vol. 9 nomor 1 (2015), hal. 80-89. Master program of environmental science, postgraduate program of udayana university.

2. Anonim, 1994. SNI-19-3241-1994 Tentang Tata Cara Pemilihan Lokasi Tempat

3. Pembuangan Akhir Sampah, Dinas Pekerjaan Umum.

4. Anonim. 2000. BSN Nomor 8 Tahun 2000 Tentang Pedoman Pemanfaatan Kawasan Sekitar TPA Sampah, Badan Standarisasi Nasional.

5. Anonim. 2001. Keputusan Menteri Permukiman dan Prasarana Wilayah No. 534/KPTS/M/2001 Tentang Pedoman Standar Pelayanan Minimal. Dinas Pekerjaan Umum.

6. Anonim. 2002. SNI 19-2454-2002 Tentang Tata Cara Teknik Operasional Pengelolaan Sampah Perkotaan. Badan Standarisasi Nasional.

7. Anonim. 2008. Undang-Undang Republik Indonesia Nomor 18 Tahun 2008 Tentang Pengelolaan Sampah.

8. Anonim, 2016. Rencana Pencegahan dan Peningkatan Kualitas Permukiman Kumuh Perkotaan (RP2KPKP) Kabupaten Kutai Kartanegara Provinsi Kalimantan Timur. Bappeda Kabupaten Kutai Kartanegara.

9. Anonim. 2019. Peraturan Daerah Provinsi Kalimantan Timur Nomor 2 Tahun 2019 Tentang Rencana Pembangunan Jangka Menengah Daerah Provinsi Kalimantan Timur Tahun 20192023. Bappeda Provinsi Kalimantan Timur.

10. Arief, Sofyan dkk. 2013. Pengelolaan Sampah Malang Raya Menuju Pengelolaan Sampah Terpadu Yang Berbasis Partisipasi Masyarakat. Jurnal Humanity. Vol.9 No.1 Hal 196-199.

11. Azmiah, N., Purnaini, R., dan Indrayadi, M. 2014. Perencanaan Sistem Pengelolaan Sampah Terpadu di Kawasan Pasar Flamboyan Kota Pontianak. Jurnal Teknik Lingkungan dan Teknik Sipil. Pontianak:Universitas Tanjungpura. Badan Pusat Statistik. 2021. Kabupaten Kutai Kartanegara Dalam Angka 2020. (Online), (https:// kukarkab.bps.go.id), diakses pada tanggal 4 Januari 2021.

12. Basriyanta, 2016. Pengelolaan Sampah Berbasis Masyarakat. Jurnal Riset Daerah. Vol 2 No. 1 Hal 7-9.

13. Brylian, B., \& Eko Setiawan, S. T. 2018. Analisis Penentuan Lokasi Tempat Pembuangan Sementara (Tps) Sampah Di Kabupaten Klaten Dengan Metode P-Dispersion (Doctoral dissertation, Universitas Muhammadiyah Surakarta).

14. Damanhuri, Enri. 2008. Diktat Landfilling Limbah, Institut Teknologi Bandung, Versi 2008, 40 
15. Diharto. 2008. Analisis Teknis Pemilihan Lokasi TPA Regional Magelang (Kota Magelang dan Kabupaten Magelang). Jurnal Teknik Sipil dan Perencanaan Nomor 1 Volume 10, Januari 2008, hal 21-28. Semarang: Fakultas Teknik Sipil, Universitas Negeri Semarang.

16. Fadhilah, Arief dkk. 2011. Kajian Pengelolaan Sampah Kampus Jurusan Arsitektur Fakultas Teknik Universitas Diponegoro. Jurnal Modul. Vol 11 No 2 Hal 62-69.

17. Hanafiah, M. (2008). Kesesuaian Lokasi TPS dari Aspek Teknis dan Pendapat Masyarakat di Kota Serang (Doctoral dissertation, program Pascasarjana Universitas Diponegoro).

18. Irawan, Bambang Irawan. Yudono, Andi Renata. 2014. Studi Kelayakan Penentuan Tempat Pemrosesan Akhir Sampah (TPA) Di Pulau Bintan Propinsi Kepulauan Riau. Jurnal Ilmu Lingkungan Prodi Teknik Lingkungan Vol 12(1):1-11,2014 ISSN : 1829-8907. Yogyakarta: Fakultas Teknik Lingkungan UPN 'Veteran' Yogyakarta.

19. Koppleman, Lee dan de Chiara, Joseph. 1978. Standar Perencanaan Tapak. Erlangga, Jakarta.

20. Milasari, lisa astria. Faktor-Faktor Yang Berpengaruh Terhadap Pemilihan Lokasi Ruko Di Kota Malang. Kurva s 6.1 (2019), hal. 32-41. Samarinda : Fakultas Teknik, Universitas 17 Agustus 1945 Samarinda.

21. Mizwar, Andy. Penentuan Lokasi Tempat Pengolahan Akhir (TPA) Sampah Kota Banjarbaru Menggunakan Sistem Informasi Geografis (SIG). Enviro Scienteae, 1978, 8.1: 16-22.

22. Neolaka, A. 2008. Kesadaran Lingkungan. Jakarta : Rineka Cipta.

23. Notoatmodjo, S. 2003. Ilmu Kesehatan Masyarakat "Prinsip-prinsip Dasar. Jakarta: Rineka Cipta.

24. Nugrahadi, B., \& Eko Setiawan, S. T. 2017. Penerapan Metode Set Covering Problem dalam Penentuan Lokasi dan Alokasi Sampah di Wilayah Kota Surakarta (Doctoral dissertation, Universitas Muhammadiyah Surakarta).

25. Paramitha, P., Hafid Munawir, S. T., \& Eng, M. 2017. Penentuan Lokasi Alternatif Tempat Penampungan Sementara (TPS) Sampah di Kabupaten Klaten dengan Metode Set Covering (Doctoral dissertation, Universitas Muhammadiyah Surakarta). Ps, T. P. 2008. Penanganan dan pengolahan sampah. Penebar Swadaya Grup.

26. Putra, Alfa Novian H. 2017. Penerapan Metode P Median dalam Penentuan Lokasi Optimal Tempat Penampungan Sementara (TPS) Sampah di Kabupatan Klaten. Jurusan Teknik Industri. Universitas Muhammadiyah Surakarta.

27. Riswan, R., Sunoko, H. R., \& Hadiyarto, A. 2011. Pengelolaan sampah rumah tangga di Kecamatan Daha Selatan. Jurnal Ilmu Lingkungan, 9(1), 31-38. Semarang:Universitas Diponegoro.

28. Risman, Z., Setiawan, Y., dan Meicahayanti, I. 2018. Pengelolaan Sampah Pasar di Kecamatan Loa Kulu Kabupaten Kutai Kartanegara dengan Menggunakan Sistem Informasi Geografis (SIG). Jukung Jurnal Teknik Lingkungan, Volume 4 Nomor 1, hal 1-11.

29. Sarwono, E., Saputro Y.I., dan Widarti, B.N. 2017. Perencanaan Pengelolaan Sampah di Kelurahan Muara Jawa Ulu dan Muara Jawa Pesisir Kabupaten Kutai Kartanegara. Jurnal Teknologi Lingkungan Vol. 1 Nomor 2, Desember 2017. Hal 27-30.

30. Sihotang, Dony M., Tarus, K., dan Widiastuti, T. 2019. Penentuan Lokasi Tempat Pembuangan Sementara Sampah Menggunakan Metode Brown Gibson Berbasis Sistem Informasi Geografis. JSINBIS (Jurnal Sistem Informasi Bisnis) Vol. 9 Nomor 2 (2019). Semarang : Universitas Diponegoro. Soemirat, Slamet. 2009. Jenis Dan Karakteristik Sampah. Jogjakarta.

31. Sub Direktorat Pengelolaan dan Pengusahaan. Direktorat Pengembangan Penyehatan Lingkungan Pemukiman. Direktorat Jendral Cipta Karya. Departemen Pekerjaan Umum. 2006. Perencanaan Prasarana dan Sarana Pengumpulan dan Pengangkutan Sampah. Bekasi

32. Sujalu, A. P., Emawati, H., \& Milasari, L. A. 2021. Ilmu Alamiah Dasar. DI Yogyakarta: Zahir Publishing.

33. Susanty, S., Triani, Y., \& Prassetiyo, H. 2012. Usulan Perbaikan Penentuan Lokasi Tempat Pembuangan Sementara (TPS) Sampah Menggunakan Metode Set Covering Problem (SCP). In Prosiding Seminar Nasional Teknoin, (pp. 195-202). Wibowo, Rudi. 2004. Konsep dan Teori Analisis Wilayah. Malang: Bayu Media Publishing.

34. Warpani, Suwardjoko. 1980. Analisis Kota dan Daerah. Bandung: Institut Teknologi Bandung. 